\title{
Employer Attractiveness to Chinese Potential Employees
}

\author{
Yiran Liu \\ Business School, University of Edinburgh
}

\begin{abstract}
Many multinational enterprises (MNE) are struggling with attaining economic revenue by controlling talent shortages in highly competitive emerging economies, such as China. Thus, competition is increasing to seem as an attractive employer by the target employees group. Employer brand building plays an important role for MNEs to attract and retain talents. However, few researches are focus on its effects on Chinese potential applicants' perceptions. This study aims to label Chinese potential employees' expectancies of future employers. It inquires to what extent employer attractiveness factors (from EmpAt) influence company reputation and intention of job application among Chinese students overseas. It asked Chinese students from three different universities in the UK to access an online survey. The conclusion is based on 300 responses to a hypothetical ideal employer. The conclusions proof that company reputation positively contributes to job applying intentions; also employer attractive factors of non-financial features, such as Interest value and application value have positive contributions to company reputation. Furthermore, some strategic advice is made for companies. The study is original because it focuses on MNEs' employer branding toward Chinese student and which will be valuable to companies in their upcoming recruitment.
\end{abstract}

Keywords: Human resources management, Corporate reputation, Employer attractiveness, Employer branding, Multinational enterprises, Recruitment

\section{Introduction}

\subsection{The Background of the study}

Many multinational enterprises (MNE) struggle for attained economic revenue and survived in highly competitive emerging economies, such as China (Sivertzen, 2013). As UNCTAD report shows, the number of Chinese employees of 100 worldfamous MNEs far exceeds that of other countries (UNCTAD, 2016). Also, the proportion of Chinese employees is increasing year by year (UNCTAD, 2016). Human resources (HR) symbolise the investment in knowledge intensive companies, which are critical for securing competitive advantage (Wright et al., 1994). The potential employees' recruitment requires a high motivation to display productive behaviours. An MNE can get an advantage by finding productive staffs and maintaining them longer than their competitors (Boxall, 1996). Company reputation and employer branding are critical for attracting the talent (Cappelli, 2001). Brand and reputation are important in the product market, and are more and more critical in the labour market as well. It is vital to measure whether the company banding strategies work in practice. Thus this paper expands the model to cover the Chinese context, and explores the relationship between employer attractiveness and company reputation.

Employer branding is based on HR theories, and pays attention to improve the picture of companies for potential employees(Jiang and lles, 2011). Only a few studies focus on the Chinese potential employees' expectation for future employers. (Anon, 2015; Jiang and Iles, 2011; Sivertzen et al., 2013; Zhu et al., 2014).

\section{Literature Review}

\subsection{Employer Branding}

Applicants often use company reputation as a reference for work environments when they compare several employers (Cable and Turban, 2003). Reputations are features, which are socially reviews according to their previous behaviours 
(Weigelt and Camerer, 1988). Employers want to reinforce their names as a brand by improving their reputation and strengthen their attractive factors, which is named employer branding.

Backhaus and Tikoo (2004) comment two transformations of branding. On one hand, employer branding is explicitly faces recruitment process and shapes the company's employer image. On the other hand, employer branding is explicitly faces audience both internal and external.Companies' internal branding focuses on employers' image creating process, its connection to employees, and employees' understanding of that image. Employer branding puts its emphasis on external people. It includes companies' self-exposition and social evaluation (Martin et al., 2005; Sivertzen et al., 2013).

Employer branding has different definitions. In this studythe author collects previous definitions to describe employer branding as structuring employer image focusing on potential employees, to distinguish the company in the industry (Backhaus and Tikoo, 2004).

The contents of employer branding vary, as employer branding is a developing concept. In this paper, the employer branding is on the resource and HR based views. Employer branding is a tool to grow employer attractive factors and expand company reputation. Some studies show that job applicants match the company's picture with their own requirements and standards (Sivertzen, 2013). Only when a job applicant's requirements and standards match the company's picture can the company enhance its attractiveness for this potential employee (Backhaus and Tiko0, 2004).

\subsection{TheEmpAt Scale}

The EmpAt scale is used to measure the employer attractive factors (Berthon et al., 2005), which evolvedfrom another scale (Ambler and Barrow, 1996). This scale contains of 25 points establishing five of them:Interest value, development value, social value, economic value and application value(Berthon et al., 2005). Interest value includes innovation and passionate for work (Ambler and Barrow, 1996 in Sivertzen, 2013). Social value covers the working environment and employees' relationship. Economic value means economic benefits. And, development value links with the potential development. Finally, application value includes the customer-oriented extent. This paper will pose its hypotheses, followed by the methodological section.

\section{Methodology}

\subsection{Research Purposes and Question}

\subsubsection{Research Purposes}

This study aims to label Chinese potential employees' expectancies of future employers. It inquires to what the extent employer attractiveness factors influence company reputation and intention of job application among Chinese students overseas.

\subsubsection{Research Question}

The research question for this study: how are Chinese potential employees' expectancies of the employer attractive factors linked to company reputation and job applying intentions? Increased knowledge of potential employees' expectancies will allow companies to shape their recruitment process and employer branding towards Chinese students more efficiently.

\subsection{Hypothesis}

When employers use employer-branding strategies, they need to identify the features, which link to a positive company brand. Because of this, companies can shape the strategies with the clear targets of attractiveness improvement. In the Berthon's (2005) study, participants were requested to rank the attractive factors of a celebrated company, against the EmpAt scale's five indicators. The positive relationship was proved between company attractive factors and the indicators. This paper takes Berthon's research deeper and involves the company reputation and application intentions as new variables with the extents of employer attractive factors. Several researches verify the relationship between a company's reputation and the employer attractiveness (Collins and Han, 2004). This paper presumes the relationship between employer attractiveness's dimensions and company reputation is unknown. In this regard, two hypotheses are as below:

Hypothesis 1:"Chinese potential employees' awareness of the five values of employer attractive factors has a positive contribution to their awareness of a positive company reputation." 
From the psychology view, Edwards (2010) finds that a company with a good reputation encourages job applications. Through a study of business students, Walter et al. (2013) demonstrates that companies' positive opinions affect the candidates' job applying intentions due to the result from a survey faces business school students at 25 European universities. In the Zhu's study (2014), company's reputation has contribution to employees' psychological contract; then it will have an impact on employees ' job applying intentions, but there is no clear statement of the relationship between the two elements. Building on the literatures this paper is testing the relationship between job applicants' awareness of company reputation and job applying intentions.

Hypothesis 2: "High company reputation has a positive contribution to the Chinese potential employees ' job applying intentions."

\subsection{Research Model}

According to the literature review and these hypotheses above, this paper built a research model as below (Figure 3.2).

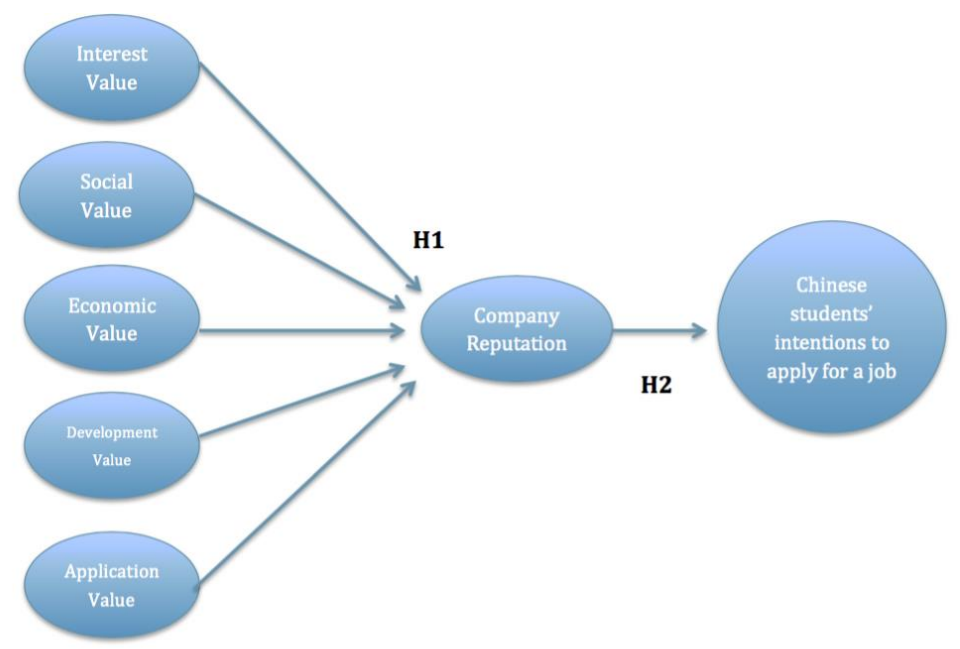

Figure 3.2 Research model

\subsection{Research Subject and Survey}

This study asked Chinese Human Resource Management (HRM) students to access an online survey about a hypothetical ideal employer. Using hypothetical employer as a research object creates some potential problems. For example, the questionnaire participants cannot combine the hypothetical employer with the actual situation; the participants imagine the hypothetical employer as the perfect employer, resulting in the subjective result (Zhu et al., 2014). However, the use of hypothetical employers simplifies the structure of questionnaires and facilitates participants to answer the questionnaire. At the same time, the hypothetical employers will also resolve the errors caused by different employers' brand promotion efforts in different regions (Zhu et al., 2014). The students fit for this study, as they have job applying intentions and are also applicants for the employer. Choosing Chinese HRM students as sample because most of them enter the job market after graduation and there is a competitive recruitment among companies. Because of the enterprise architecture development in MNEs according to Chinese economy booming, the headquarters has more complex control over HRM activities and needs more HRM professionals (Chen et al., 2016). However, the current Chinese HRM's higher education cannot provide enough talents for MNEs (Li and Sheldon, 2010). There is a competition for Chinese HRM overseas returnees among MNEs (Cooke and Wang, 2014). Thus, employer branding is of special interest among this field.

Considering that for Chinese HRM students, if this survey directly names specific MNEs as future employers, some participants may not be familiar with those companies and will not have enough knowledge to answer the questions. In order to solve this problem, this study does not give designated employers, but provides a hypothetical ideal employer, so that the students can complete the survey according to their own image of ideal employer. 
There is no transformation of the scale in this survey. The respondents are all Chinese students, who study in the UK. They should achieve at least grade 6.5 in the International English Language Testing System (IELTS) with the admission requirements, which means they can fully understand the questionnaire and address it appropriately. Moreover, more complex questions were placed at the front of the survey to attract the attention of the responders, and demographic questions were placed at the bottom.

\subsection{Measures}

\subsubsection{Employer attractiveness}

Employer attractiveness is testedagainst five values from the Berthon et al.'s (2005) EmpAt Scale. This paper chooses five out of 25 dimensions from the scale, namely, interest value, development value, social value, economic value and application value(Berthon et al., 2005). A five-point Likert Scale covers 5 levels (strongly agree to strongly disagree/1-5) was used.

\subsubsection{Company reputation}

Company reputation is tested using Turban et al.'s (1998) scale. In the Zhu's study (2014), this scale is used to measure the reputation of the company and proved to be effective in the final analysis of results. This scale involves four indicators, for example, "I have heard a lot of good things about this firm". This part uses the Likert scale as well.

\subsubsection{Intentions to apply for a job}

Intentions was tested using the scale build by Highhouse et al. (2003), such as, "I would accept a job offer from this company", with the Likert scale applied.

\subsubsection{Control variables}

Several control variables, for example, gender, age, academic results, and work experience, are included.

\section{Presentation and Results}

The Statistical Package for the Social Sciences (SPSS Ine, 2000) software package version 24 was used to analyse the data.The first section examines the accuracy of research measures by using reliability and factor analysis. The second section offers the inter-correlation among all variables. The mean and standard deviation of the each factor is shown. Finally, the hypotheses are verified through hierarchical regression analysis. In addition, the conclusions will be given at the very end of this part.

\subsection{Data Gathered Overview}

\begin{tabular}{|c|c|}
\hline Number of Questionnaires Distributed & 300 \\
\hline Number of Questionnaire Collected Back & 300 \\
\hline Response Rate & $100 \%$ \\
\hline Number of Questionnaire Used For Analysis & 300 \\
\hline
\end{tabular}

\section{Figure 4.1 Sample Profile}

The sample profile of the survey is presented in Figure 4.1 the link to the online survey was accessible to the Chinese HRM students at the University of Edinburgh, Edinburgh Napier University and Heriot-Watt University in the UK. There is a total of 300 sets selected respondents. 


\subsection{Data Presentation}

\begin{tabular}{|c|c|c|c|}
\hline Variables & Categories & Frequency & Percentage (\%) \\
\hline Gender & Male & 90 & 30 \\
& Female & 210 & 70 \\
\hline Age & Under 20 & 0 & 0 \\
& $21-24$ & 270 & 90 \\
& $25-29$ & 20 & 3 \\
\hline Work Experience & Above 30 & 10 & 90 \\
& Under 1 year (include 1 year) & 270 & 3 \\
& From 1-3 years (include 3 years) & 10 & 7 \\
& From 3-5 years (include 5 years ) & 20 & 0 \\
\hline
\end{tabular}

Figure 4.2 Demographic Characteristics of Respondents

\subsection{Reliability Analysis}

\begin{tabular}{|c|c|c|}
\hline Variables & Number of Items & Cronbach Alpha \\
\hline The five EmpAt factors (Total) & 15 & 0.860 \\
Interest value; & 3 & 0.486 \\
Social value; & 4 & 0.645 \\
Economic value; & 2 & 0.817 \\
\hline Development value; & 2 & 0.705 \\
\hline Application value. & 4 & 0.672 \\
\hline Company reputation & 2 & 0.847 \\
\hline Intentions to apply for a job & 3 & \\
\hline
\end{tabular}

Table 4.3 Results of Reliability Test

The Cronbach Alpha of each item is presented in Figure 4.3. From this Figure above, the Cronbach Alpha values of Interest Value is lower than the standard. Therefore, the invalidity problem (Innovation Q2) is removed and the corrected Cronbach Alpha is reached 0.773 . Others' Cronbach Alpha is ranged from 0.645 to 0.860 . This Reliability analysis can ensure all used items are no error (Rashid et al., 2015). 


\subsection{Descriptive Analysis}

\begin{tabular}{|c|c|c|}
\hline Variables & Mean & Standard Deviation \\
\hline The five EmpAt factors (Total) & 1.83 & 0.88 \\
Interest value; & 1.55 & 0.80 \\
Social value; & 1.42 & 0.59 \\
Economic value; & 1.42 & 0.62 \\
\hline Development value; & 1.8 & 0.70 \\
\hline Application value. & 1.57 & 0.62 \\
\hline Company reputation & 1.57 & 0.65 \\
\hline Intentions to apply for a job & & \\
\hline
\end{tabular}

Figure 4.4 Descriptive Analysis

All the variables' means and standard deviations are shown in Figure 4.4. The range of all means is between 1.57-1.83. Mean is used to measure the central tendency due to its mathematical qualities; the value, which exceeds the maximum and minimum limits, is named as average and sensitive (Rashid et al., 2015). In Figure 4.4, the interest value has the highest mean of 1.85 and the highest standard deviation of 0.88 . It means the fluctuation of the sample data is bigger than others.

\subsection{Factor Influence Company Reputation towards Chinese Potential Employees}

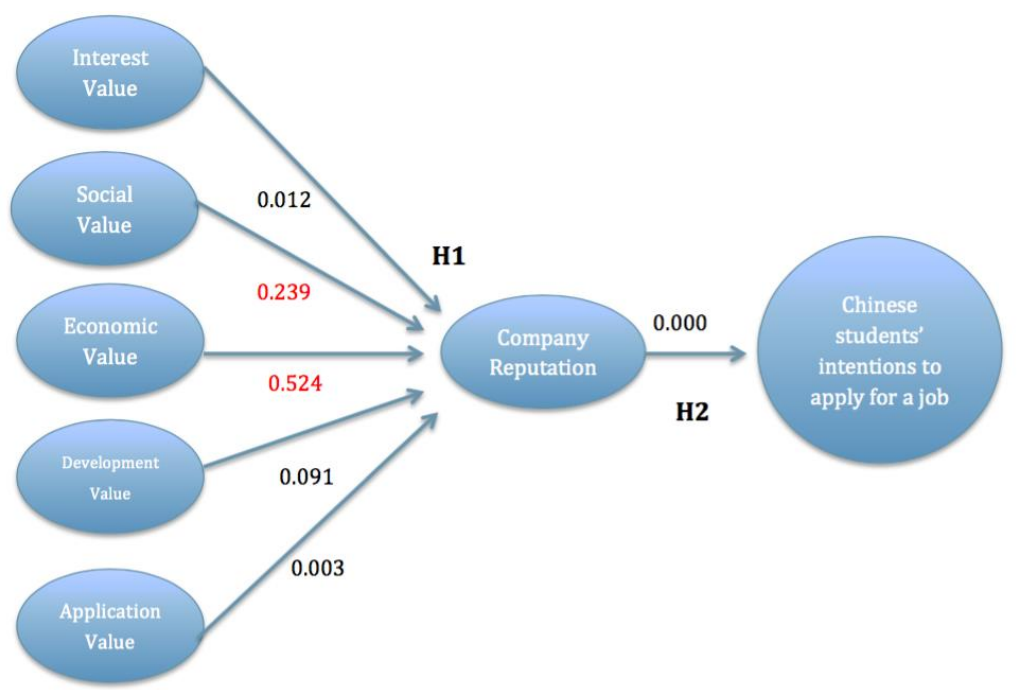

Figure 4.5 Results of Regression Analysis on Turnover 
The results of significant effectbetween each variable from the regression analysis presented in Figure 4.5. The general level of significant effectis not good. However, compared to other variables, the economic value have the weakest significant effect, which is Sig $t=0.524$ with the company reputation. This presented that economic value was not an indicator that will affect the company reputation towards Chinese potential employees. Similarly, the result can prove that both the social value and the development value cannot influence the company reputation. Thus, this paper can find that hypothesis 1 is partly confirmed as a consideration that affecting the company reputation as three out of five values were not indicators and there is a significant positive relationship between the EmpAt and company reputation, $r(28)=.427, p=.000$ ( $P$ value $<.05)$. The regression analysis shows that the company reputation has significant effect with the job applying intentions towards Chinese potential employees, due to the Sig $t=0.000$ and $r(28)=.632, p=.000$ ( $P$ value < .05). Consequently, the hypothesis 2 is accepted.

\subsection{Conclusion}

This part will show hypothesis testing' consequences in Figure 4.6. It analyze through the statistic data above.

\begin{tabular}{|c|c|c|}
\hline $\begin{array}{c}\text { No of } \\
\text { Hypothesis }\end{array}$ & Statement of Hypothesis & Results \\
\hline H1 & $\begin{array}{c}\text { Chinese potential employees' awareness of the five values of employer } \\
\text { attractive factors has a positive contribution to their awareness of a positive } \\
\text { company reputation. }\end{array}$ & Accepted \\
\hline H2 & $\begin{array}{c}\text { High company reputation has a positive contribution to the Chinese } \\
\text { potential employees ' job applying intentions. }\end{array}$ & $\begin{array}{c}\text { Partly } \\
\text { Accepted }\end{array}$ \\
\hline
\end{tabular}

Figure 4.6 Results of Hypothesis Testing

\section{Conclusion}

\subsection{Conclusion}

This paper examines relationships between the EmpAt scale (Berthon et al., 2005), company reputation, and job applying intentions in an employer-branding standpoint so as to discover critical features a company should pay attention to in the employer branding strategies. All two hypothesesare accepted, though hypothesis 1 is partly accepted. Based on the results of data analysis, this study found that not all five employer attractive values have a positive link with employees' awareness of good employer's reputation.

First, the accuracy of this EmpAt scale has changed their linked indicators according to the originalscale. It may be because of the cultural differences between the scale country of origin (Australia) and China. One of the main reasons can be the cultural dimension of individualism versus collectivism; in Jie's report (2012), he scores Australian individualism dimension as 90 and only 20 for China. The more collectivist countries attach more importance to corporate reputation because people generally believe that groups with good reputation will bring benefits to individuals. However, at the individual level, the factors for evaluating whether a group has a good reputation are also more complicated (Zhu, F. et al., 2014). This result is also different from the study of Arachchige and Robertson (2011). Their studies used eight factors, beyond the 25 indicators from the original scale and three new ones were created. All three of these new factors are related to the psychological contract between employees and companies, the psychological factors may have not been fully considered in this study. This could be the explanation for the difference in results.

Second, this paper identifies employer attractive factors that Chinese potential employees may need to value in companies. Precisely, conclusions proof that the attractive factors of five values apart from social, economic and development value have positive contributions to company reputation. Consequently, non-financial features of the employers may be more critical to build a good reputation of the company to Chinese job applicants. The absence of social value is debated, since the working environment in social relations may also be important. The absence of development value is complex to clarify. 
One likely clarification may be that it is hard to evaluate self-feelings in a hypothetical ideal employer, than it is to evaluate it in a specific named company.

In Berthon et al.'s (2005) study, all five values in the EmpAt scale indicate the importance for potential employees' awareness of the company brand. Following this paper's results, companies should highlight innovation, self-worth, confidence, training, and the possibility of employee practice rather than financial reward in their employer branding strategies. Moreover, some similar theories were found in attractive factors of disabled employees (e.g. Nadeau and Olafsen, 2015), and non-financial features are more considerable in recruiting and maintaining staffs (Hiltrop, 1999). That the social value dimensions play a less important role may be because the Chinese overseas students' social characteristics. Many of them are used to living far away from their hometowns, lack of social life (Wu, 2016). Thus, social value is not their priority when seeking a job.

The company reputation has a positive relationship with job applying intentions. Moreover, this finding shows that Chinese HRM potential employees appear to choose a company that gives them a better self-feeling as future employer. This conclusion links to the importance of psychological contract with employer to maintain staffs (Wu, 2012).

Last but not least, not unexpectedly, this paper finds that company reputation positively contributes to job applying intentions, consistent with previous studies (Sivertzen, 2013).

\subsection{Practical Implications}

To the HR practitioners, the findings of this paper offer some proposals. Firstly, the employer branding strategies for the recruitment process should focus on non-fanatical features and avoid 'only driving employees by money'. Especially, this paper highlights the importance of application values as well as innovation values for Chinese candidates, when they appraise their ideal employers. This covers innovation, self-worth, confidence, training, and the possibility of employee practice. Those factors may improve job-applying intentions in Chinese job applicants. Secondly, companies that need Chinese employees with HRM professional background, or general talents, should shape their recruitment strategy against this appraisal as well.

In the practice of the company, group cooperation training based on solving practical problems in the work can be applied, so that the employees can understand the practical problems in the training, and also strengthen the confidence in solving the problems in the future work. At the same time, this kind of training can also help cultivate the innovative spirit of the employees. For example, in Google China, solutions and even patents generated during the training process can be applied to practical work (Feldman, 2012). This can increase the number of patents copyrights owned by the company, because employees' invention patent rights belong to the company during the work hours (Feldman, 2012), and it can also give employees a win-win opportunity to learn more skills.

\subsection{Limitations and Further Research}

This paper has several limitations. Firstly, because all conclusions are according to the survey data, assumptions link to the relations between variables are unjustified.

Secondly, Chinese HRM students are selected as respondents for this survey as they are popular for MNEs. This causes the competition of hiring talents between those companies, and they will highlight employer branding for Chinese HRM employees. The situation may differ from position to position and country to country. Generally speaking, using Chinese students as respondents is a double-edged sword. For the negative part, it may reduce external validity (Wells, 1993, in Sivertzen, 2013). In this paper, Chinese HRM students as a homogeneous group may isolate the results. Besides, this paper selects Chinese students from non-Chinese universities. Their expectations may differ from those students studying domestically. For the positive part, companies have graduate schemes whose target employees are mainly students. Hence this paper can be used as theoretical references for those schemes.

Thirdly, in terms of the outputs from the reliability test of the EmpAt scale one item was removed. Yet the theoretical appraisal proofs that items are credible. Finally, a mixture of data analysis methods may be used for related topics in future studies, considering the limits of small sample group adopted by this paper.

\section{References}

[1] Ambler, T. and Barrow, S. (1996), "The employer brand", The Journal of Brand Management, 4(3), pp. 185-206. 
[2] Anon, 2015. Employer Branding Company HiAll Successfully Lists on New Third Board Market, A First for A Chinese Employer Branding Consultancy. Pharma Business Week, p.67.

[3] Arachchige, B.J.H. and Robertson, A. (2011), "Business student perceptions of a preferred employer: a study identifying determinants of employer branding", The IUP Journal of Brand Management, 8(3), pp. 25-46.

[4] Backhaus, K. \&Tikoo, S., 2004. Conceptualizing and researching employer branding. Career Development International, 9(5), pp.501-517.

[5] Berthon, Pierre, Ewing, Michael \& Hah, Li Lian, 2005. Captivating company: dimensions of attractiveness in employer branding.(concepts of internal marketing)(Author Abstract). International Journal of Advertising, 24(2), pp.151-172.

[6] Boxall, P., 1996. The Strategic Hrm Debate and the Resource-Based View of the Firm. Human Resource Management Journal, 6(3), pp.59-75.

[7] Cable, D.M. \& Turban, D.B., 2003. The Value of Organizational Reputation in the Recruitment Context: A Brand-Equity Perspective. Journal of Applied Social Psychology, 33(11), pp.2244-2266.

[8] Cappelli, P., 2001. Making the most of on-line recruiting. Harvard Business Review, 79(3), pp.139-146.

[9] Chen, L., Su, Z.-X. \& Zeng, X., 2016. Path dependence and the evolution of HRM in China. The International Journal of Human Resource Management, 27(18), pp.2034-2057.

[10] Collins, C.J. \& Han, J., 2004. Exploring Applicant Pool Quantity and Quality: The Effects of Early Recruitment Practice Strategies, Corporate Advertising, and Firm Reputation. Personnel Psychology, 57(3), pp.685-717.

[11] Cooke, Saini \& Wang, 2014. Talent management in China and India: A comparison of management perceptions and human resource practices. Journal of World Business, 49(2), pp.225-235.

[12] Edwards, M.R., 2009. An integrative review of employer branding and OB theory. Personnel Review, 39(1), pp.5-23.

[13] Feldman, R., 2012. Rethinking patent law, Cambridge, Mass.: Harvard University Press, 11(1), pp.3-13.

[14] Hiltrop, J.-M., 1999. The quest for the best: human resource practices to attract and retain talent. European Management Journal, 17(4), pp.422-430.

[15] Jiang, T. \& lles, P., 2011. Employer-brand equity, organizational attractiveness and talent management in the Zhejiang private sector, China. Journal of Technology Management in China, 6(1), pp.97-110.

[16] Jie, Yun, Chou, Ting-Jui\& Chou, Naichieh, 2012. Assessing the fit of two brand personality scales in a Chinese context and revisiting the predictive validity of two methods of measuring self-congruity. Journal of Brand Management, 19(6), pp.525540.

[17] Li, Y. \& Sheldon, P., 2010. HRM lives inside and outside the firm: employers, skill shortages and the local labour market in China. The International Journal of Human Resource Management, 21(12), pp.2173-2193.

[18] Martin et al., 2005. Branding: A New Performance Discourse for HR. European Management Journal, 23(1), pp.76-88.

[19] Matsueda, R.L., 1991. Structural Equations with Latent Variables. (Book Review). American Journal of Sociology, 96(6), pp.1553-1555.

[20] Nadeau, J. \&Olafsen, A., 2015. Country image evaluations and migration intentions. Place Branding and Public Diplomacy, 11(4), pp.293-308.

[21] Rashid et al., 2015. THE IMPACT OF SERVICE QUALITY AND CUSTOMER SATISFACTION ON CUSTOMER'S LOYALTY: EVIDENCE FROM FAST FOOD RESTAURANT OF MALAYSIA. International Journal of Information, Business and Management, 7(4), pp.201-258.

[22] Sivertzen, A.-M., Nilsen, E.R. \&Olafsen, A.H., 2013. Employer branding: employer attractiveness and the use of social media. Journal of Product \& Brand Management, 22(7), pp.473-483.

[23] Walter, Sascha G, Parboteeah, K. Praveen \& Walter, Achim, 2013. University Departments and Self-Employment Intentions of Business Students: A Cross-Level Analysis. Entrepreneurship Theory and Practice, 37(2), pp.175-200.

[24] Weigelt, K. \&Camerer, C., 1988. Reputation and corporate strategy: A review of recent theory and applications. Strategic Management Journal, 9(5), pp.443-454.

[25] Wright, P.M., Mcmahan, G.C. \&Mcwilliams, A., 1994. Human resources and sustained competitive advantage: a resourcebased perspective. The International Journal of Human Resource Management, 5(2), pp.301-326.

[26] Wu, B., 2016. Chinese Student Migration, Social Networking, and Local Engagement in the uk. Journal of Chinese Overseas, 12(1), pp.40-67.

[27] $\mathrm{Wu}, \mathrm{X} \& \mathrm{Wu}, \mathrm{Zm}, 2012$. The gap between pre-employment and post-employment psychological contract and its correlates. International Journal Of Psychology, 47, p.527.

[28] Yalcin, E. et al., 2016. Der UNCTAD World Investment Report 2016: Die EntwicklungausländischerDirektinvestitionen/The UNCTAD World Investment Report 2016: The development of foreign direct investment. IfoSchnelldienst, 69(22), pp.42-50.

[29] Zhu, F. et al., 2014. RECONSIDERING THE DIMENSIONALITY AND MEASUREMENT OF EMPLOYER BRAND IN THE CHINESE CONTEXT. Social Behavior and Personality, 42(6), pp.933-948. 
